\title{
Probing Islamic Values of Business Principles and Ethics
}

\author{
Iffatin Nur ${ }^{1}$, Binti Nur Asiyah ${ }^{2}$, Reni Dwi Puspitasari ${ }^{3}$, Syamsul Umam $^{4}$ \\ 1, 2, 3,4 The State Islamic Institute (IAIN) of Tulungagung - East Java, Indonesia
}

\begin{abstract}
In Islam, business is one of the most important parts of mu'āmalah (worldly transaction) and gets a very serious attention. Islam teaches the values that must be obeyed and followed by its adherents when conducting business. Unfortunately, the present reality shows that there are still many Muslims who prefer opting and practicing business principles and methods that may not contain and display Islamic values in their practices. This paper is aimed to explore what values are taught by Islam in conducting a good and permissible business, principally and ethically. The study was a library research employing the discourse analysis. The results of this study show that Islam teaches a very comprehensive concept of business pertaining to its principles and ethics. They also show that, contrary to conventional business principles, Islamic ones accentuate the aspect of divinity in business. This is so because the basic principles and ethics taught by Islam through its maqāșid sharī'ah in conducting mu'āmalah, in this case doing business, are meant to none other than bring benefits to mankind justly and proportionally as well as resisting any harm from them.
\end{abstract}

Keywords: business ethics; Islamic values; maqāṣid sharī'ah; mu'āmalah

\section{Introduction}

The environment of the 21st century's global business which is increasingly complex puts corporates of every size facing miscellaneous issues of ethics. Therefore, business corporates are responsible to develop an array of codes of ethics and conducts that their members must follow and act accordingly. Basic issues of ethics in business must be based on trust and integrity, whereas more complex issues such as empathetic decision-making, accommodating diversity, governance, and compliance have to be in line with a company's fundamental values (Oster and Seidel 2019).

Many business scandals - including those occurred in the Wall Street Stock Exchange marked by so many deceits in their business' conducts such as frauds, cheatings, and extortions (cf. finance.detik.com 2005; Rezy 2015; InterestTrip 2018) - have rendered many companies to give particular and heavy attention on their ethical standards in conducting business. This is so since business ethics are regarded capable to serve as the control agent to alter negative things into positive ones or, minimally, to eliminate negative practices in industrial, business, and economic activities.

Whenever a company wants to record and gain success in its business, according to Richard De George (2009), it needs three main things, namely: good products, smooth management, and ethics. These three prerequisites must be present together. So, even though a company owns a good quality of their product which is beneficial to many people and it is managed with appropriate management in the fields of production, human resources, finance, distribution, etc., but lacks of ethics, such shortfall will sooner or later serve as a stumbling block for it (Rofiah 2014).

The importance of ethics in business is inevitable; there are a lot of facts showing that several businesses in the United States and other countries experience problems due to unethical conducts practiced by people in their companies. A quite recent case of the 1MDB scandal in Malaysia provides a valid and irrefutable proof of the importance of exercising business ethics (Sari 2015). Such unethical conducts can be practiced in a variety of business systems within a company namely in the production, distribution, products promotion, marketing systems, in the way obtaining the company's capital, and so on. 
Business is not merely oriented to collecting material and financial benefits, but also must pay attention to ethics and morality. In fact, violations of business ethics are still common in Indonesia. Business practices that have taken place so far are considered to still tend to ignore a sense of justice and ethics, and many times colored with practices that are not commendable or moral hazard (Kristanto 2010). The corruption phenomenon in Indonesia, - almost in all sectors and involving a variety of lines of society's members: bureaucrats, businessmen, policy makers, and so forth,- shows that business practices in this country are not conducted in accordance with business ethics. It is sad and ironic, - bearing in mind that Indonesia is a country with the largest Muslim population in the world,- learning a release from the International Transparency which stated that in 2018 Indonesia's Corruption Perception Index (CPI) rose to 38 and it ranked 89th out of all countries in the world. Zero point denotes the most corrupt country; the upper a country's rank, the less corruption is found and practiced in that country (Saputra 2019). So, when observing any practice that display business ethics, we will have ourselves in the field of morality and its definition (Goel and Ramanathan 2014: 50). Business activities will then be valued not by what is effective or efficient but by what is defensible morally (Wozniak 2011: 304).

The principles taught by Islam in every matter, including conducting business, is none other than for bringing maslahah (benefit) to mankind as well as rejecting mafsadah (harms) from them. This is where maqāșid sharì'ah (Islamic purposefulness) in mu'ämalah (worldly transaction among mankind) must be present. As Allah has stated in the Quran when sending His Prophet Muhammad (peace be upon him, pbuh) to us by bringing with him Islamic teachings is as a mercy to all the universe, He says in the Holy Qur'an Surah (QS) al-Anbiyā [21]: 107: “Wa mā arsalnāka illā rahmatan li al- 'ālamìn"'(We sent thee not for but a mercy for all creatures) (Ali 1992: 818).

The question that naturally arises is whether Islam offers and teaches any value regarding to conducting business so that in doing so the main mankind's purpose of attaining benefits for both phases of their lives can be realized. This becomes the purpose of this study which is to probe Islamic values of business principles and ethics. However, it is acknowledged to be a merely small part of many researches studying the issue of Islamic business principles and ethics. Even so, the results of this study are hoped to give a contribution to the literatures on Islamic business ethics.

\section{Research Methodology}

This study was library research employing discourse analysis and content analysis, thus, the source of this research is pure literature (Kothari 2004; Zed 2008; Sugiyono 2013). In this research, the authors analyzed the language in its widest sense, including, mostly by studying documents (Bakker and Zubair 1992; Shaw and Bailey 2009). The method of data collection in this study used the documentary technique. This was due to the problem's characteristic and the nature of the research. A documentary technique is a way of collecting data through the written heritages, - especially in the form of books, periodicals, articles, etc.about opinions, theories, arguments/postulates and others which have relations with the problems being researched (Nawawi 1991: 133). The techniques of data analysis used the descriptive method. As explained by Nawawi (1993: 81), the descriptive method of a research is a research by describing the state of the subject (person, organization, society, etc.) based on the facts that appear as they are. Characteristically, the descriptive method is a fact-finding method and gives interpretations on those facts.

\section{Result and Discussion}

\section{a. The Definition of Terms}

Prior to discussing the theme, let's take a look of some definitions related to the title of this paper. The word maqāșid (single: maqșid) has the closest meaning to an objective, a purpose, an intent, a principle, a goal, an end (Ibn 'Ashur 2006: 2), or finalité (French), telos (Greek), or Zweck (German) (von Jhering 2001: 35). Meanwhile, Jasser Auda (2008: xxiii) explained that the term shari'ah means the revelation sent to the Prophet Muhammad (pbuh) that he made implementing it as the message and his life's mission, in the form of the Qur'an and the Sunnah. The world mu'āmalah (plural: mu'āmalāt) means an act involving interaction and exchange among people such as sales and sureties (Esposito 2003) or worldly transaction among people (Auda 2008: 330). In this paper, what the authors mean by maqāșid sharī 'ah' fi al-mu'ämalah in the title of this study is the purposes wanted by the Shäri ' (the Law Maker, Allah the God Almighty) in establishing the law for His servants' benefits regarding wordly transactions among them. 
The word probing means a thorough and careful investigation of something (Turnbull 2014); business, which in this case is associated to worldly transaction, literally means the activity of producing, buying, selling or supplying goods or services for money (Turnbull 2014), whereas ethics (single: ethic) means moral principles that control or influence a person's behavior (Turnbull 2014).

The word business had been a common day-to-day word and its definition had also been widely given by various experts, which relate to these meanings: company, affairs or venture (Alma 1997: 15). Etymologically, the word business comes from an old English bisignes (a Northumbrian word) which means anxiety, care, occupation. It originates from the word bisig (adj.) which means busy, anxious, careful, diligent, occupied (www.etymonline.com/word/business).

The word ethic (pl. ethics) is etymologically known from the word ethik of the late 14th century. It means study of morals. It originates from Late Latin ethica, from an Old French etique which means ethics, moral philosophy (13rd century), from Greek èthike philosophia which means moral philosophy, from the word èthikos which means ethical, relating to character, and from èthos meaning moral character. The sense of meaning of ethic as moral principles of an individual or a group of people is proved to be used from 1650s (www.etymonline.com/word/business).

In this study, the word ethic is defined as a set of rules that define right and wrong conducts or a batch of moral principles which distinguish good from bad (Muslich 2004: 1). Whereas Schemerhorn (2008: 32) defined ethic as the code of moral principles that defines standards of good or bad, and right or wrong behaviors. Ethical behavior is what is regarded as right or good as opposite of wrong or bad in the governing moral code context. Muslich (2004: 7) stated further that ethic is a philosophy or fundamental and critical thoughts on the values, norms, teachings, and the customs of moral perspectives. In brief, Hashi (2011) summarized that ethic is a standard that defines what a man ought to do, including virtues, attitudes, and obligations both as individuals and as a part of society (cf. Widana et al. 2014).

The business ethics' concept started in the 1960s as many companies got aware more of a growing consumer-based society that concerned towards their environment, their social issues, and corporate responsibility. The increased attention and concern on so-called social issues was an endorsement of the decade (Singer 2019). Since that time period, the business ethics' concept has developed. It goes beyond merely a moral code of right and wrong; it tries to reunite whatever companies have to legally do against preserving a competitive profit over other businesses. Companies demonstrate business ethics in many ways. One important thing to bear in mind is that, according to Singer (2019), business ethics are purposed to make sure the presence of a certain degree of trust between companies and consumers to guarantee the public equal and fair treatment.

Terminologically, business ethics is defined as the system of moral and ethical beliefs that guides the values, behaviors and decisions of a business organization and the individuals within that organization (Horton 2019). A particular attention to ethics is more clearly understood by talking about issues of the social responsibility of those organizations related to a variety of stakeholders therein (Muhammad 2002: 73). Business ethics make sure that a certain basic grade of trust does exist between consumers and a variety of market participants (Twain 2019).

Meanwhile, as a science, business ethics is defined as the study of proper business practices and policies relating to subjects which are potentially controversial including bribery, insider trading, corporate governance, corporate social responsibility, fiduciary responsibilities, and discrimination. Twain (2019) further states that the law often provides guidance to business ethics, however, at other times it is business ethics that provide a basic direction that businesses may opt to follow to obtain public approval.

\section{b. Observing Conventional Business Principles and Ethics}

In a capitalist system, in which business is an unseparable part of it, economics is defined as a study of humans, especially humans as homo economicus, in which their behaviors are driven by scarcity of resources to achieve certain goals. An economic human is assumed to be rational in all his/her behaviors, however the term rational meant here is narrowly interpreted, since it refers to egoistic rational. This is because all human conducts are considered to be guided and directed by his/her own personal interest which is to maximizing his/her own satisfaction and benefit (Kuncoro 1997). One thought about having an enduring business even suggested to 'act as if your competition is trying to eat your lunch.' That is what competitors do. Such a competition happens in a business niche where some people feel they can take 
advantage of one's weaknesses and exploit their competitive advantages. In this case, as quoted by Silverman (2018), Andy Grove, the former chairman of Intel Corporation, said, "Only the paranoid survive".

Essentially, business principles and ethics give guidance about how a company works. They consist of anything ranging from how honest a company in conducting small detailed of their business practices to how good and fair they treat their workers, and many things in between (Gilbeau 2018). Now, many thoughts come forward suggesting the importance of exercising business ethics. Some that may help construct an ethical business and contribute most are integrity, honesty, trustworthiness and promise-keeping, customer safety and concern for others, strong and ethical leadership, and accountability.

Relating to integrity, Gilbeau (2018) explains that an ethical business must not disregard on what is right and wrong. Both parties of a business activity must stick to their integrity. Ethical businesses must not alter their values as they proceed or try to make more profits. Whereas Josephson (2010) states that integrity must be demonstrated even at the time there is great pressure to do the opposite; it must be made as a principle, be honored, and be stood upright. It shouldn't be sacrificed in return of expediency.

Meanwhile, honesty relates to making honest commitments both within the internal business organization as well as to clients. Honesty also means to always commit oneself to what he/she can do and the timeline needed to do so. Empty promises both to inside people and to clients must be avoided. So, being truthful and honest in all dealings and never deliberately deceive or mislead others by overstatements, misrepresentations, selective omissions, partial truths, or any other conducts must become a common practise in a business activity (Josephson 2010; Stewart 2019).

The sustainability of business activities also rely on the presence of trust and promise-keeping. This includes business participants' ability to carry out timely and quality work and then to deliver it on time. Trust is needed in providing relevant information, in correcting misunderstanding of facts, and in fulfilling the promises and commitments. Just like Josephson's (2010) statement that an unreasonably legalistic or technical manner in effort to justify non-compliance or create excuses for getting away from commitments must not be conducted. Furthermore both sides must also have secure feeling that the business they involve in is done in a fair and truthful manner as well as abide honorable practices.

Furthermore, ethical businesses must take the aspect of customer safety seriously. They have to aim keeping those who use their services and products safe, even though if it means to delay a product release, to carry out a product recall, or to make other important policies and decisions. Good characters such as compassionate, caring, kind, and benevolent should be practiced. Gilbeau (2018) asserted that the Golden Rule that states 'helping those in need and seeking to fulfill their business purposes in a way that depicts the least disadvantage and attains the greatest benefit' must be applied. An ethical business pays appropriate concern to anything and anyone influenced and effected by the business. They include employees, customers, vendors, public in general, and the environment surrounding it. Therefore, Phillips and Seidel (2019) reminded us that every business decision must take good consideration on the impacts it may result in on anyone of those said people or on the surrounding environtment.

Then, every organization needs a leader to operate well. Leaders can set up and exemplify good conducts to those under their supervision. So, an ethical business culture can start from the very top of an organizational hierarchy. For having an ethical business, its leaders have to demonstrate ethical conducts in any condition and should become positive ethical pattern practicing good conducts (Josephson 2010). Leaders who are regarded as ethically positive will influence their employees to work productively (Brown and Trevino 2006; Mayer et al. 2009; Brown and Mitchell 2010: 583). An essay by Joplin et al. (2019) shows that low ethical leadership results in hindered job performance. A strong and ethical leadership may be seen in the decision-making process at the time they have to choose between what will give financial profit or gain and what is ethically acceptable. Those who can choose consciously the way that is correct ethically, contrary to one that is just financially driven, have created successfully a business ethical culture. When such culture is rigid at the top of an organization, it spreads over to all employees and areas (Joplin et al. 2019).

Lastly, a good business has to show good accountability. It is a control mechanism requiring accountors to justify and explain what they do so that it is understood to be necessary or not for the accountee to impose sanctions to control the accountor's conduct (Mulgan 2000; Bather and Arunachalam 2015: 22). Measurement of performance and techniques of evaluation are central to the aspect of controllability's accountability and are meant to preserve close control of services and resources (Chouinard 2013; Bather and Arunachalam 2015: 22). 


\section{c. The Prophet Muhammad (pbuh) as the Exemplary Role Model in Conducting Business}

Observing the history of the Prophet Muhammad's conduct related to his business activities is always an interesting study. It is of no surprise, since we believe that Muhammad was indeed prepared by Allah to become the best role-model to mankind regarding all of human activities, religiously and worldly, including conducting business. As Allah asserts this matter in QS al-Najm [53]: 3-4: "Wa mā yanțiqu 'anil hawā. In huwa illā wahyun yūhā" (Nor does he say (aught) of (his own) desire. It is no less than inspiration sent down to him) (Ali 1992: 1377). Even Michael Hart (2000: 2) in his book titled 'The 100: A Ranking of the Most Influential Persons in History' placed him at the top of the list. He did so by acknowledging that Muhammad was the only man in history who was supremely successful on both the religious and secular levels. This is because his moral is based on the teachings of the Quran as Aishah said when she was asked about the Prophet's manner: "Kāna khuluquhū al-Qur 'an" (His manner is the Quran) (Ibn Hibban 1993: no. 2542; Muslim 2001: no. 746; Abu Dawud [n.d.]: no. 1342).

Talking about his profession, Muhammad became a very skilled and influential businessman owing to his environment since he was a little child to his teenage and such was sharpened even more after his marriage to Khadijah. The business experiences that he gained before he became a prophet was the fruit of his struggle with his social reality in the jahiliyyah (ignorant) time. And after Allah made him His prophet at the age of 40 years old, part of his experiences were poured in his sayings which are called hadith (Saifullah 2010: 42).

Muhammad had the gene of becoming a skilled businessman from his ancestors. His father, Abdullah, and his uncle, Abu Talib, were merchants. He grew up in Mecca, a trading city. What he saw and felt in Mecca prepared him to become a merchant. The opportunity came over when he was under the care of Abu Talib. During his care, Muhammad often visited and sold in some high populated cities with their wellknown markets such as 'Ukaz, Majinna, Żul Majaz, Basra, and so forth. Unfortunately, his desire to participate in a trading caravan was always declined by Abu Talib on his safety reason. After his uncle felt that his desire to participate in the trading caravan got stronger, Abu Talib gave him permission. At that moment, he could witness how to travel long distances and how economic transactions were conducted. By joining the trading caravan, he read the geographical and economic conditions of Mecca, the thing that later on became a motivator for him to pursue business rather than farming or shepherding as his field of profession (Saifullah 2010: 43).

Muhammad's marriage to Khadijah was a perfect match. When he was still Khadijah's employee, he was known as a hard worker, tenacious, and honest, whereas Khadijah was a wealthy widow. Thus, Muhammad must fight hard to manage her wealth. The property management was done by him professionally. After his marriage, he continued his trading business as before and started acting as a manager and a partner in his wife's business. Since his marriage when he was 25 years old until his prophetic call of duty arrived when his age was 40 years old, Muhammad had made trade journeys to various places including the Arabian Peninsula, the countries at the borders of Syrian, Bahrain, Iraq, Yemen, and so forth (Karim 2002: 19). He learned a lot from his wife and his trading journeys about conducting business. This became a strong factor encouraging him to become a businessman because of his wife's wealth was impossibly neglected. He must be good at managing merchandise as well as paying attention to the welfare of their employees (Karim 2002: 39).

Plenty of good manners were exemplified by the Prophet Muhammad (pbuh) as narrated in many hadith discussing business practices; in conducting all transactions, he did them honestly and fairly, he never had his costumers dissappointed, he always kept promises, he sold merchandise with the quality wanted and agreed by his customers, and he also demonstrated a sense of responsibility in any transaction he made. His transparency and honesty in conducting business is, according to Nawawi (2013: 98), a timeless legacy of exemplary manners for the next generation of businessmen.

\section{d. Islamic Principles of Conducting Mu'āmalah}

'Divine guidance' is the fundamental aspect of mu'ämalah; therefore, it creates a gap between the Islamic method of conducting business and the secular one. The divinity aspect of business activity of a Muslim businessman/businesswoman, according to Arslan (2009: 53), puts him/her apart from a secular one whose main objective in his/her doing business is merely to maximize profit. Islam commands a divine call for devout Muslims to do business that is beyond mere profit. 
Islam has given guidance to mankind of how they should conduct their activities of life, both regarding to 'ibādah (ritual worship to Allah) and mu'ämalah. Such guidance is based mainly on the Quran and the Sunnah, as well as other sources of Islamic laws including ijmā (Muslim scholar's consensus), qiyās (analogical deduction), and so forth. Here are some principles of mu'ämalah taught by Islam (cf. Habibullah 2018) and which are in accordance with maqāṣid sharīah:

1. Conducting mu'amalah is a part of obedience to Allah in its wider sense just as conducting other ritual practices of 'ibādah as Allah says in QS 'Āli 'Imrān [3]: 112: "Shame is pitched over them (like a tent) wherever they are found, except when under a covenant (of protection) from Allah and from men"(Ali 1992: 1497). In QS al-Mulk [67]: 2, He says: "He who created death and life, that He may try which of you is best in deed" (Ali 1992: 156). Therefore, any man's activity must be intended for the sake of Allah, as he/she will or will not get reward from Allah based on his/her intention. The Prophet (pbuh) said:"Actions are according to intentions, and everyone will get what was intended"(al-Bukhari 1998: no. 54; Muslim 2001: no. 746).

2. Any activity related to mu'ämalah must be based on the principle of jalbu al-mașālih wa dar'u almafāsid (attaining benefits and resisting harms). So, a business transaction made must abide this principle and must not cause the opposite. In this case, trading of harmful products such as liquors, drugs for abusive use, etc. does not conform with this principle. However, when implementing Islamic teachings more substantively to be in line with the demands of the dynamic and fast development of era, culture, and technology, Muslich (2004: 30) emphasized that a process of ijtihād (intellectual exercise) and re-interpretation of the texts of the Quran and the Sunnah both textually and contextually is necessitated.

3. Such activity must also in line with the principle of raf'ul haraj wa taysìr (alleviating difficulties and promoting ease). A business activity must be intended to lift difficulties experienced by those involved whether related to their needs for products or services and must not bring otherwise. In this case, Islam teaches us to help each other (ta'āwun) in conducting mu'ämalah so that wealth becomes a means for spreading goodness that benefits to all. In QS al-Baqarah [2]: 280, Allah says:"If the debtor is in a difficulty, grant him time till it is easy for him to repay, but if ye may remit it by way of charity, that is best for you if ye only knew" (Ali 1992: 116).

4. All properties/wealth belong to Allah who has given them to mankind as one of the many bounties for his/her benefits as He says in QS al-Nahl [16]: 53: "And ye have no good thing but is from Allah: and moreover, when ye are touched by distress, unto Him ye cry with groans" (Ali 1992: 650). Allah empowers man to manage and use his/her wealth (istikhlāf al-māl ) but he/she will be accounted for it before Him later in the hereafter. Therefore, the way of obtaining and using it must be in accordance with His provisions as He says in QS al-An'ām [6]: 165: "And it is He Who hath made you His agents, inheritors of the earth: he hath raised you in ranks, some above others: that He may try you in the gifts He hath given you: for thy Lord is quick in punishment: yet He is indeed Oft-Forgiving, Most Merciful" (Ali 1992: 343). And the Prophet (pbuh) said: "Verily, Allah will ask every person about his/her authority over whatever he/she has power over it, whether he/she guards his/her trust or abusing it" (Ibn Hibban 1993: Vol. 10, no. 4492).

5. Being proportional and fair in distribution. A Muslim is prohibited from excessive use even of his/her own property, but he/she must use it effectively and efficiently and avoid both the attitudes of being ifrat (excessive) or tafrīt (underestimating). Allah says in QS al-Isrā' [17]: 29 : "Make not thy hand tied (like a niggard's) to thy neck, nor stretch it forth to its utmost reach so that thou become blameworthy and destitute" (Ali 1992: 682). The Prophet (pbuh) said: "Eat, drink, give alms, and dress without a stingy and extravagant attitude"(Ibn Hanbal 1978: Vol. 5, no. 6695).

6. Ownership of property is not the purpose of a man's life, but it is only a means to enjoy what Allah has given to him/her through His good fortune so that he/she can take advantage from them in realizing public benefits, as In QS al-Anfāl [8]: 26, He says: "Call a mind when ye were a small (band), despised through the land, and afraid that men might despoil and kidnap you, but He provided a safe asylum for you, strengthened you with His aid, and gave you good things for sustenance: that ye might be grateful " (Ali 1992: 420). And the Prophet (pbuh) said: "Verily the world is sweet and green and indeed Allah handed over to you all in it. Then Allah will see how you do with the world (i.e. all the wealth). So beware of the world and the women" (Muslim 2001: no. 2742). 
However, Allah permits mankind to develop their property and prohibits monopolies and hoarding it. This principles explains about extending the scope of utilizing one's property for public benefit (mașlahah al- 'ammah) as His saying in QS al-Tawbah [9]: 34-35: "O ye who believe! There are indeed many among the priests and anchorites, who in falsehood. Devour the substance of man and hinder (them) from the way of Allah. And there are those who bury gold and silver and spend it not in the way of Allah: announce unto them a most grievious penalty. On the day when heat will be produced out of that (wealth) in the fire of hell, and with it will be branded their foreheads, their flanks, and their backs. "This is the treasure which ye buried for yourselves, taste ye, then, the treasures ye buried"(Ali 1992: 447-448). Again, the Prophet (pbuh) said: "No muslim plants a plant nor a tree, then a bird, a human or an animal eats from it, but for him a charity" (al-Bukhari 1998: Vol. 6, no. 2320).

7. Obtaining wealth and distributing, utilizing, and spending it must be done in permissible ways. Islam prohibits any attempt to obtain property that would cause malice, undermine human relationships, or by deceptive conducts, cheating, etc. Likewise, Islam commands anyone to do justice in conducting business so that public social and mental damages may be avoided. Allah says in QS al-Nahl [16]: 90 :"Allah commands justice, the doing of good, and liberality to kith and kin, and He forbids all shameful deeds, and injustice and rebellion: He instructs you that ye may receive admonition" (Ali 1992: 861). Meanwhile, the Prophet (pbuh) said as narrated by Jabir ibn Abdullah, "Allah is pleased with someone who facilitates the sale, simplifies in buying, and eases in collecting debts"( (al-Bukhari 1998: Vol. 5, no. 2076). In another hadith, he (pbuh) also said: "Harm not and do not be harmed" (Ibn Majah [n.d.]: 2340).

8. Islam forbids practices of ribā (usury) and obtaining wealth by misconducts. The harm of usury is due to the mastery of others by illegal ways and prohibited to take wealth by misconducts (unlawful methods) for they can cause enmity and hatred in society. Allah says in QS al-Rūm [30]: 39:”That which ye lay out for increase through the property of (other) people, will have no increase with Allah: But that which ye lay out for charity, seeking the countenance of Allah, (will increase). It is those who will get a recompense multiplied" (Ali 1992: 1018). The Prophet (pbuh) said: "God curses the people who eat the usury, who give usury, who write the transaction and the two witnesses. He says: They are all the same" (Muslim 2001: Vol. 5, no. 2742).

9. In conducting mu'ämalah, the agreement binds both parties in transaction. This is ordered by Allah as He says in QS al-Mā'idah [5]: 1 : "O ye who believe! Fulfill (all) obligations" (Ali 1992: 243), and in QS al-Isrā' [17]: $34 \mathrm{He}$ further says:"And fulfill (every) engagement, for (every) engagement will be enquired into (on the Day of Reckoning)" (Ali 1992: 683). Therefore, recording a transaction process is necessary to safeguard it from disputes, forgetting, losing, and others. Islam teaches authentication (tawthiq) through recording, testimonials, pawn assurance, etc. to protect any right of the owners. Allah says in QS al-Baqarah [2]: 282 -283 about this: "O ye who believe! when ye deal with each other in transactions involving future obligations in a fixed period of time, reduce them to writing, let a scribe write down faithfully as between the parties...etc" (Ali 1992: 117-118). A hadith narrated by Aishah reads: "The Prophet (pbuh) had bought food from a Jewish trader by credit and he (the Prophet) pawned him his armor" (al-Bukhari 1998: Vol. 2, no. 1962; Muslim 2001: Vol. 3, no. 1603).

10.The state's intervention must be present in creating a balanced distribution of resources, so hoarding or stockpiling as commonly seen nowadays is forbidden in Islam. This is because Islam prohibits the concentration of wealth only on a bunch of people that prevents the wider community from enjoying its benefits. He says in QS al-Hashr [59]: 7: "What Allah has bestowed on His Messenger (and taken away) from the people of the township belongs to Allah, to His Messenger, and to kindred and orphans, the needy and the wayfarer; in order that it may not (merely) make a circuit between the wealthy among you. So take what the Messenger assigns to you, and deny yourselves that which he withholds from you. And fear Allah, for Allah is strict in punishment" (Ali 1992: 1444). In line with this verse, the Prophet (pbuh) said: "Mankind are allies in three things: pastures, water, and fire" (Abu Dawud [n.d.]: no. 3479).

\section{e. Islamic Teachings of Business Ethics}

Islamic business ethics are based on the teachings of Islam themselves and had been exemplified by the Prophet Muhammad (pbuh) who was sent to mankind by Allah to perfect their akhlāq (ethics/morals). In one hadith narrated by al-Bukhari (1998: no. 273), the Prophet (pbuh) said: "Innamā bu'ithtu li utammima 
makārima al-akhlāq" (Verily I am sent to perfect noble characters). So, the normative foundation of Islamic business ethics is derived from none other than the main sources of Islamic teachings which are the Quran and the Sunnah since they have been providing any business executant their references to manage or run their businesses in Islamic way (Muslich 2004: 30; Nawawi 2013: 97). Some of business ethics that Islam teaches are:

1. Tawhïd (oneness of Allah). It means bringing the sense of tawhìd into all aspect of life, i.e. whenever practicing both 'ibādah and mu'ämalah, including business activities. Tawhìd is the focal and central point of Islamic thought. Its implementation means conducting mutual care among mankind and taking care of universal welfare. In brief, tawhi d brings faiths regarding one's relation to his/her Creator (hablun min Alläh) and attitudes to other fellow beings and universe with all its contents (hablun min al$n \bar{a} s)$ all together in a perfect package of a man's conduct.

2. 'An tarädin wa hurriyyah (based on willingness of all parties involved and freedom). Willingness and freedom (absence of coercien element) are necessary pre-requisite for any mu'ämalah activity as these are the starting point of conducting a business for attaining true benefits from it. Allah says in QS alNisā' [4]: 29: "O ye who believe! Eat not up your property amongst yourselves for vanities, but let there be among you traffic and a trade by mutual good will" (Ali 1992: 193-194). The Prophet (pbuh) said: "A trade transaction is on willingness" (Ibn Hibban 1993: no. 4967; Ibn Majah [n.d.]: 2180). He said further:"Two persons who buy and sell are free to choose before they split. If both are honest and forthright in buying and selling, then both of them will get a blessing. However, if both of them do not speak up (i.e. about the true condition of the merchandise) and lie, then the transaction they do will not be a blessing" (al-Bukhari 1998: no. 1937; Muslim 2001: no. 1825). Likewise, on the occasion of haji wadā' (the Farewell Pilgrimage) the Prophet (pbuh) also said: "Your life and happiness are sacred and inviolable by each other until the end of the day" (cf. Muslich 2004: 43). By having his/her ownership of property recognised, a businessperson will be able to utilize their properties more properly based on the freedom to do any effort (ikhtiyār).

3. Șidq wa amānah (being honest and trustworthy). In the Islamic doctrine, honesty and trustworthy are fundamental requirements in business activities. The Prophet (pbuh) was very intense in encouraging Muslims to be honest and trustworthy in their business activities. He himself was always honest in conducting business. He forbade traders to put down rotten goods on the bottom pile and new ones on top to deceive the prospecting buyers. These two attitudes are implemented by not taking one's rights more than what they should be and, at the same time, not reducing the rights of others from their appropriate portion, keeping all promises, respecting agreements, being punctual, and so forth. In QS alNisā' [4]: 105 Allah says: "We have sent down to thee the book in truth, that thou mightest judge between men as guided by Allah: so be not (used) as an advocate by those who betray their trust" (Ali 1992: 220). The Prophet (pbuh) said: "An honest and trustworthy trader will be gathered with the prophets, the righteous persons, and the martyrs in the hereafter" (al-Turmużi [n.d.]: no. 1209). He (pbuh) also said: "It is not permissible for a Muslim to sell a defect merchandise, unless he explains it (in advance)"(Ibn Majah [n.d.]: 2246). He said further: "Whoever deceives us is not one of us" (Muslim 2001: no. 102).

4. 'Adl wa musawwā (being fair and upholding equity). Islam commands its followers to be fair and upholding equity even to those who are not liked whether they are Muslims or not. Moreover, being fair must take precedence over conducting good deeds since by doing so means placing someone closer to the path of piousness. In QS al-Mā'idah [5]: 8, Allah says: "O ye who believe! Stand out firmly for Allah, as witnesses to fair dealing, and let not the hatred of others to you make you swerve to wrong and depart from justice. Be just! That is next to piety, and fear Allah. For Allah is well acquainted with all that ye do" (Ali 1992: 248). In business practices, these attitudes may be realized in treating business counterparts fairly, sharing with them appropriate rights and compulsaries, treating people in the business company justly regarding their rights for wages, welfare, comfortable working environment, career promotion, etc.

5. Ta'äwun wa rahmah (helping each other and being merciful): These attitudes relate to one's behavior to give benefits to other people sincerely. They are contrary to the self-interest principle as practiced in conventional businesses. They project generosity and goodness, encompass mercy, forgiveness, tolerance, justice, and attentiveness. By having such etics in conducting mu'ämalah (in this case is business), the wealth will become a means for spreading goodness that benefits to all. As a result, 
interaction and relationships with others will be treated as primarily personal and non-discriminatory so that benefits of any business deals will go beyond one's immediate and self- interests and at the same time avoid maximizing one's own benefit at the expense of others (Ali 2011; Arslan 2009: 49). Allah says in QS al-Mā'idah [5]: 2: "Help ye one another in righteousness and piety, but help ye not one another in sin and rancour" (Ali 1992: 243-244). As an example of its implementation, in QS alBaqarah [2]: 280 Allah commands Muslim to ease debtors who are in difficulty to repay either by granting them more time or remitting the debts as a charity for them (Ali 1992: 116).

6. Tawäzun (being in equilibrium/balance). This means maintaining balance between the present needs and the future ones, the wordly aspects and the heavenly ones, the individual interest and the communal one, the material and spiritual needs, etc. Having this attitude, according to Rice (1999) will avoid manners of dishonesty, greed, and disrespect to others' needs and rights, which the modern capitalism may sometime encourage. Its implementation can be in the forms of not deceiving marketing information, not plasticizing questionable pricing practices, being moderate in consumption, saving resources for future generations, and producing good policies for wealth distribution. Allah says in QS al-Qașaș [28]: 77 :"But seek, with the (wealth) which Allah has bestowed on thee, the home of the hereafter, nor forget thy portion in this world" (Ali 1992: 982).

7. Ikhläs (being sincere). This means that a business is conducted by holding the truth both in words and acts, honesty in intention and thought, and avoiding false pretenses and hypocritical manners. Having such attitudes, a Muslim will become a modest, humble, and friendly person and demonstrates no discrimination among fellow Muslims, especially, and to other human being in general. $\mathrm{He} / \mathrm{she}$ will not mislead nor cheat others by hiding known defects on his/her trading merchandises nor violating agreed transactions. Allah says in QS al-Ghāfir [40]: 65: "He is the Living (One), there is no God but He: call upon Him, giving Him sincere devotion. Praise be to Allah, Lord of the universe"(Ali 1992: 1223).

\section{Conclusion}

From the above discussion, it can be concluded that Islam actually teaches us remarkable values pertaining principles and ethics in conducting business activities. Those values, which are contained in the Quran and the Hadith and exemplified by practices of the Prophet Muhammad (pbuh), guide every Muslim conducting their mu'āmalah activities, including business. Those activities must not only consider this present wordly needs and benefits but also aim to attain prosperous life in the hereafter. All of mu'amalah activities are eventually purposed to attaining benefits to mankind justly and proportionally as well as resisting any harm from them. Such is in line with realizing one of the roles of mankind as the vicegerents of Allah on this earth which is to demonstrate Islam as a religion of rahmatan li al- 'älamin (a blessing to all the universe).

\section{Acknowledgment}

The study was self-funded, however, we would like to express our sincere gratitude to librarians at the IAIN Tulungagung - East Java for their tireless and time consuming assistance in providing materials (books, journals, magazines, etc.) to us during our research. We also declare that there is no conflict of interest in whatsoever form regarding the future publication of this paper.

\section{References}

[1] "24 Fakta Berlebihan tentang Skandal Wall Street," InterestTrip, 2018, https://id.interestrip.com/1727id-24-slimy-facts-about-wall-street-scandals, [accessed on Jan 20, 2019].

[2] Ali, Abdullah Yusuf. (1992). The Meaning of the Holy Qur'an. Maryland, USA : Amana Corporation, ISBN-10: 0915957116, ISBN-13: 978-0915957118

[3] Ali, A. J. (2011). "Islamic Ethics and Marketing". In Ozlem, S \& Rice, G. (Eds.) Handbook of Islamic Marketing. UK.: Edward Elgar Publishing Limited.

[4] Abu Dawud. [n.d.]. Sunan Abu Dawūd, Vol. 3, Beirut-Lebanon: Dar al-Fikr.

[5] Alma, Buchari. (1997). Pengantar Bisnis. Bandung-Indonesia: Alfabeta.

[6] Arslan, Zeynep. (2009). "Islamic Business Ethics and Its Impact on Strategic Business Decision Making Process of Muslims", MBA Thesis, Burnaby-BC, Canada: Simon Fraser University. 
[7] Auda, Jasser. (2007). Maqashid Shariah as Philosophy of Islamic Law: A Systems Approach. London-UK: IIIT. ISBN: 978-1-56564-425-0.

[8] Badroen, Faisal, et al. (2006). Etika Bisnis Islam. Jakarta-Indonesia: Kencana.

[9] Bather, Andrea \& Arunachalam, Murugesh. (2015). "Accountability for Business Ethics in the Context of Financial Markets Authority's Corporate Governance Principles". Journal of Applied Business Research. 13(19).

[10] Bakker, Anton and Zubair, Ahmad Haris. (1992). Metodologi Penelitian Filsafat. YokyakartaIndonesia: Kanisius.

[11] Brown, Michael E. and Mitchell, Marie S. (2010). "Ethical and Unethical Leadership: Exploring New Avenues for Euture Research", Business Ethics Quarterly 20(4): 583-616.

[12] Brown, M. E., \& Treviño, L. K. (2006). "Socialized charismatic leadership, values congruence, and deviance in work groups". Journal of Applied Psychology, 9(1): 954-962.

[13] al-Bukhari, Muhammad. (1998). Șaḥị̄ al-Bukhārī. Riyadh, KSA: Baitul Afkar Al-Dauliyah.

[14] Chouinard, J. A. (2013). "The Case for Participatory Evaluation in an Era of Accountability". American Journal of Evaluation, 34(2): 237-253.

[15] De George, Richard T. (2009). Business Ethics, $7^{\text {th }}$ ed., London-UK: Pearson. ISBN-10: 0205731937, ISBN-13: 978-0205731930.

[16] Esposito, John L. (2003). Oxford Dictionary of Islam, Oxford-UK: Oxford University Press.

[17] Gilbeau, Terry L. (2018). "5 Things That Point to an Ethical Business", http://gilbeaulaw.com/5things-that-point-to-an-ethical-business/ [accessed on Feb, 24, 2019].

[18] Goel, Mridula and Ramanathan, Preeti E. (2014). "Business Ethics and Corporate Social Responsibility - Is there a dividing line?" Procedia Economics and Finance, 11: 49 - 59, https://doi.org/10.1016/S2212-5671(14)00175-0

[19] Habibullah, Eka Sakti. (2018). "Prinsip-prinsip Muamalah dalam Islam", Ad-Deenar: Jurnal Ekonomi dan Bisnis Islam, 2(1): 25-48, doi: 10.30868/ad.v2i01.237. [accessed on Feb 3, 2019].

[20] Hart, Michael. (2000). The 100: A Ranking of the Most Influential Persons in History, Revised edn. New York-USA: Citadel. ISBN-10: 9780806513508, ISBN-13: 978-0806513508.

[21] Horton, Melissa. (2019). "Why is Business Ethic Important?", Investopedia, Feb 25. https://www.investopedia.com/ask/answers/040815/why-are-business-ethics-important.asp. [accessed on March 2, 2019].

[22] Ibn 'Ashur, Mohammad al-Tahir. (2006). Ibn Ashur, Treatise on Maqāṣid al-Sharī'ah, translated by Muhammad el-Tahir el-Mesawi, London-UK: International Institute of Islamic Thought (IIIT). ISBN: 9781565644229.

[23] Ibn Hanbal, Imam Ahmad. (1978). Musnad Imām Aḥmad ibn Hanbal, Vol. 5, Cairo-Egypt: Muassasah Qurtubah.

[24] Ibn Hibban. (1993). Shaḥ̄ḥ Ibn Hibbān, Beirut-Lebanon: Muassasah al- Risalah.

[25] Ibn Majah, Muhammad bin Yazid. [n.d.]. Sunan Ibnu Majah. Beirut-Lebanon: Dar al-Fikr.

[26] Joplin, T., et al. (2019). "Employee Entitlement, Engagement, and Performance: The Moderating Effect of Ethical Leadership", Journal of Business Ethics, 1-14, https://doi.org/10.1007/s10551-019$\underline{04246-0}$

[27] Josephson, Michael, (2010). "12 Ethical Principles for Business Executives" www.josephsononbusinessethics.com/2010/12/12-ethical-principles-for-business-executives/ [accessed on Feb, 24, 2019].

[28] Karim, Adiwarman Anwar. (2002). Sejarah Pemikiran Ekonomi Islam, Jakarta-Indonesia: IIIT.

[29] Kothari, C. R. (2004). Research Methodology: Methods and Techniques. $2^{\text {nd }}$ ed. New Delhi-India: New Age International. ISBN (13) : 978-81-224-2488-1.

[30] Kristanto, Purnawan. (2010). 'Etika Bisnis untuk Keberlanjutan Usaha,' Kompasiana, March 14. https://www.kompasiana.com/purnawan/54ff8fd4a33311f44d510549/

[31] etika-bisnis-untuk-keberlanjutan-usaha. [accessed on Jan 25, 2019].

[32] Kuncoro, Mudrajat. (1997). "Ekonomi Islam, Konsep dan Metodologi”, Jurnal Ekonomi dan Bisnis Indonesia, 12(1). https://jurnal.ugm.ac.id/jieb/article/download/39926/

[33] 22498. [accessed on Feb 25, 2019].

[34] Mayer, D. M., et al. (2009). "How low does ethical leadership now? Test of a trickle-down model", Organizational Behavior and Human Decision Processes, 108: 1-13. 
[35] Muhammad. (2002). Etika Bisnis Islam. Yogyakarta-Indonesia: UPP AMP YKPN.

[36] Mulgan, R. (2000). "Accountability: An Ever-Expanding Concept". Public Administration, 78(3): 555-573.

[37] Muslich. (2004). Etika Bisnis Islami. Yogyakarta-Indonesia: Ekonisia.

[38] Muslim, Imam. (2001). Șahịḥ Muslīm. Riyadh, KSA: Maktabatur Rusyd.

[39] Nawawi, Hadari. (1991). Metode Penelitian Bidang Sosial. Yogyakarta-Indonesia: Gadjah Mada University Press.

[40] Nawawi, Hasyim. (2013). "Islamic Business Ethics Between Reality and History", KARSA, 21(1): 88-102.

[41] Oster, Kenneth V. and Seidel, Michelle. (2019). "List of Ethical Issues in Business", Jan 28. https://smallbusiness.chron.com/list-ethical-issues-business-55223.html [accessed on Feb 6, 2019].

[42] Phillips, Cindy and Seidel, Michelle. (2019). "Six Characteristics of an Ethical Business", Feb 1. https://smallbusiness.chron.com/six-characteristics-ethical-business-22401.html [accessed on Feb 6, 2019].

[43] Rezy, Fakhri. (2015). "Skandal Volkswagen Buat Wall Street Anjlog," OKefinance, Sept 23. https://economy.okezone.com/read/2015/09/23/213/1219378/

[44] skandal-volkswagen-buat-wall-street-anjlok, [accessed on Jan 15, 2019].

[45] Rice, G. (1999). "Islamic ethics and the implications for business". Journal of Business Ethics, 18: 345-358.

[46] Rofiah, Khusniati. (2014). "Urgensi Etika di dalam Sistem Bisnis Islam", Justicia Islamica, 11(2): 161-186, DOI: 10.21154/justicia.v11i2.100. [accessed on Jan 23, 2019].

[47] Saifullah, Muhammad. (2010). "Kajian Sejarah: Etika Bisnis dalam Praktek Mal Bisnis Muhammad", Economica, 2(2): 27-46.

[48] Salvador, R. \& Folger, R. (2009). "Business ethics and the brain". Business Ethics Quarterly, 19: 131.

[49] Saputra, A. (2019). "Indonesia Ranking 89 Indeks Persepsi Korupsi Dunia”, detikNews, Jan 29. https://.news.detik.com/foto-news/d-4405951/indonesia-ranking-89-indeks-persepsi-korupsi-dunia. [accessed on Jan 15, 2019].

[50] Sari, Yoko. (2015). "Mengenal 1MDB, sumber Kisruh di Malaysia", CNN Indonesia, August 30. https://www.cnnindonesia.com/internasional/20150830161922-106-

[51] 75445/mengenal-1mdb-sumber-kisruh-di-malaysia. [accessed on Feb 2, 2019].

[52] Schemerhorn, J. R. (2008). Management, Hoboken, NJ : Wiley.

[53] Shaw, S.E. and J. Bailey. (2009). "Discourse analysis: what is it and why is it relevant to family practice?," Family Practice 26(5): 413-419. doi:10.1093/fampra/cmp038

[54] Silverman, Stan. (2018). "7 Principles for Building an Enduring Business", The Business Journal, June 4. https://www.bizjournals.com/bizjournals/how-to/

[55] growth-strategies/2018/06/7-principles-for-building-an-enduring-business.html [accessed on Feb 4, 2019].

[56] Singer, Peter. (2019). "Ethics", Encyclopedia Britannica, Online: May 22. https://www.britannica.com/topic/ethics-philosophy. [accessed on May 23, 2019].

[57] Stewart, David. (2019). "Key Elements for Business Practices", bizfluent.com, Jan 22. https://bizfluent.com/info-8737061-key-elements-business-ethics.html, [accessed Feb 3, 2019].

[58] Sugiyono. (2013). Metode Penelitian Kuantitatif, Kualitatif, dan R\&D, $19^{\text {th }}$ ed., Bandung-Indonesia: Alfabeta. ISBN : 979-8433-64-0.

[59] al-Turmużī, Imam. [n.d.]. Sunan al-Turmużī, Beirut-Lebanon: Dar Ihya al-Turath al-'Arabi.

[60] Turnbull, Joanna. (2014). Oxford Advanced Learner's Dictionary, Oxford-UK: Oxford University Press, ISBN-10: 0194799484, ISBN 13: 9780194799485, Available for online search: https://www.Oxfordlearnersdictionaries.com/definition/english/ [Accessed on Feb 12, 2019].

[61] Twain, Alexandra. (2019). "Business Ethics", Investopedia, June 25. https://www.investopedia.com/terms/b/business-ethics.asp. [accessed on June 27, 2019].

[62] von Jhering, Rudolf. (2001). Law as a Means to an End (Der Zweck im Recht), translated by Isaac Husik, $2^{\text {nd }}$ reprint ed., New Jersey-USA: The Lawbook Exchange (Originally published 1913 by Boston Book Co.,). ISBN-13: 9781584770091. ISBN-10: 1584770090. 
[63] "Wall Street Terguncang Skandal Seks Bos Boeing", 2005. detikfinance, March 8. https://finance.detik.com/bursa-dan-valas/d-312404/wall-street-terguncang-skandal-seks-bos-boeing, [accessed on Jan 13, 2019].

[64] Widana, G. N. O., et al.. (2014). "Measuring Islamic Business Ethics Within Indonesia Islamic Banks", Global Journal Al-Thaqafah, 4/2(7): 5-15. DOI: 10.7187/GJAT622014.04.02.

[65] Wozniak, A. (2011). "The missing subject found in the subject who does the thinking: Kierkegaard, the ethical and the subjectivity of the critical theorists." Business Ethics: A European Review, Volume 20(3), https://doi.org/10.1111/j.1467-8608.2011.01630.x [accessed on Feb 11, 2019].

[66] www.oxfordislamicstudies.com/article/opr/t125/e1564, [accessed on Feb 20, 2019].

[67] Zed, Mestika. (2008). Metode Penelitian Kepustakaan, Jakarta-Indonesia: Yayasan Obor Indonesia, ISBN: 9789794618882.

\section{Authors' Biography:}

1) An Associate Professor at the Graduate School of IAIN Tulungagung. Currently the Head of Master courses program in Islamic Law on Family and Islamic Law on Economy. Holds an undergraduate degree from the State Islamic University (UIN) of Sunan Ampel, Surabaya, a Master and a Doctorate degree from the State Islamic University (UIN) of Syarif Hidayatullah, Jakarta, all in Islamic law (Shari'ah).

2) A senior lecturer at the Graduate School of IAIN Tulungagung at the Master course program in Islamic Law on Economy. Holds a first degree from the State Islamic Institute (IAIN) of Tulungagung in Islamic Education, a Master degree from the University of Indonesia in Economy, and currently is completing her doctorate degree at the State Islamic University (UIN) of Sunan Ampel, Surabaya in Islamic Economy.

3) A lecturer at the Graduate School of IAIN Tulungagung at the Master course program in Islamic Law on Family. Holds a first degree and a Master degree from the State Islamic Institute (IAIN) of Tulungagung in Islamic Law.

4) A lecturer at the Graduate School of IAIN Tulungagung at the Master course program in Islamic Law on Economy. Holds a first degree from the Islamic Institute of Tribakti, Kediri in Islamic Law and a Master degree from the Islamic University of Malang in Law. 